\title{
Renewal of the Advanced Photon Source
}

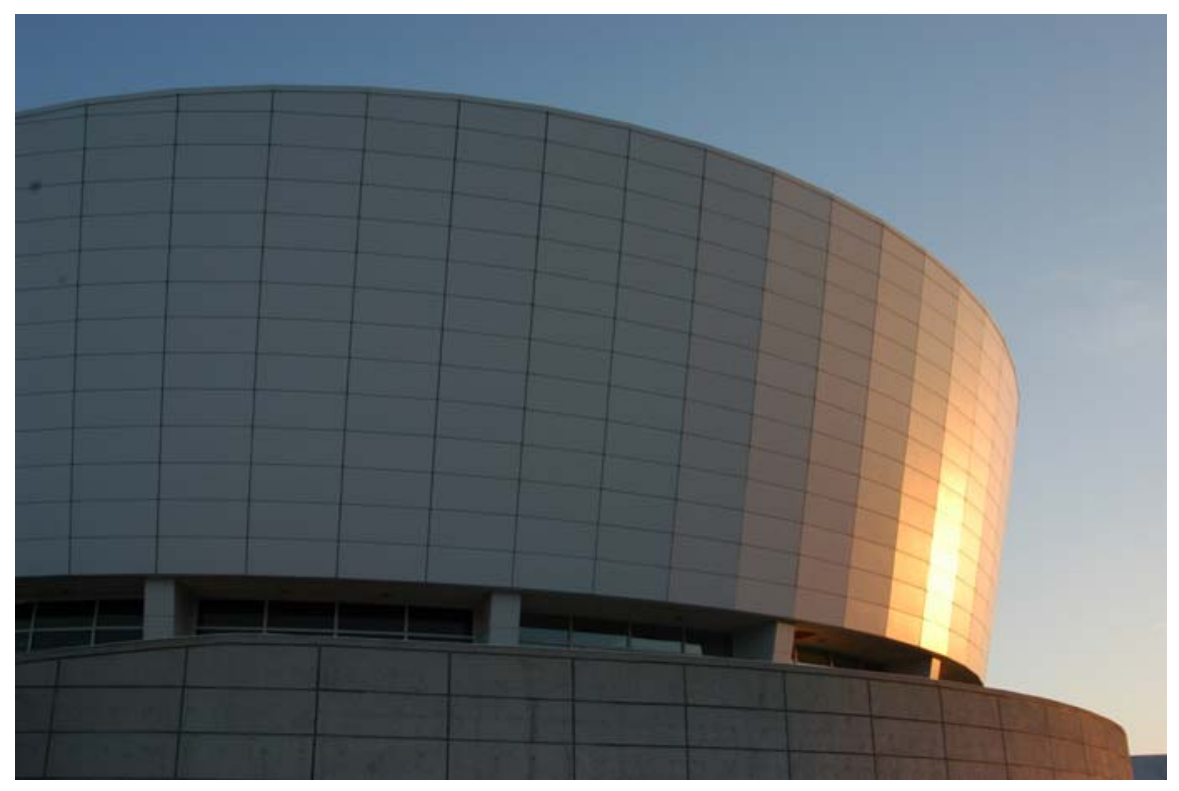

A white paper prepared for the

Department of Energy, Office of Science,

Office of Basic Energy Sciences

by the management and users of the

Advanced Photon Source

November $1^{\text {st }}, 2008$

Contact: imgibson@aps.anl.gov 
Argonne is managed by UChicago Argonne, LLC, for the U.S. Department of Energy under contract DE-AC02-06CH11357. The Laboratory's main facility is outside Chicago, at 9700 South Cass Avenue, Argonne, Illinois 60439. For information about Argonne and its pioneering science and technology programs, see www.anl.gov.

The Advanced Photon Source at Argonne National Laboratory is supported by the U. S. Department of Energy, Office of Science, Office of Basic Energy Sciences, under Contract No. DE-AC02-06CH11357.

Availability of This Report:

This report is available at no cost, at http://www.osti.gov/bridge. It is also available on paper to the U.S. Department of Energy and its contractors, for a processing fee, from:

U.S. Department of Energy

Office of Scientific and Technical Information

P.O. Box 62

Oak Ridge, TN 37831-0062

phone (865) 576-8401

fax (865) 576-5728

reports@adonis.osti.gov

DISCLAIMER

This report was prepared as an account of work sponsored by an agency of the United States Government. Neither the United States Government nor any agency thereof, nor UChicago Argonne, LLC, nor any of their employees or officers, makes any warranty, express or implied, or assumes any legal liability or responsibility for the accuracy, completeness, or usefulness of any information, apparatus, product, or process disclosed, or represents that its use would not infringe privately owned rights. Reference herein to any specific commercial product, process, or service by trade name, trademark, manufacturer, or otherwise, does not necessarily constitute or imply its endorsement, recommendation, or favoring by the United States Government or any agency thereof. The views and opinions of document authors expressed herein do not necessarily state or reflect those of the United States Government or any agency thereof, Argonne National Laboratory, or UChicago Argonne, LLC. 


\section{Executive Summary}

To ensure that state-of-the-art hard x-ray tools are available for US scientists and engineers who are solving key problems in energy, environment, technology development and human health, the nation's unique high-energy x-ray source needs a major renewal of its capabilities. The Advanced Photon Source renewal program responds to key scientific needs driven by our user community. The renewal encompasses many innovations in beamlines and accelerator capabilities, each of which will transform our tools and allow new problems to be solved. In particular the APS renewal dramatically expands two compelling avenues for research. Through x-ray imaging, we can illuminate complex hierarchical structures from the molecular level to the macroscopic level, and study how they change in time and in response to stimuli. Images will facilitate understanding how proteins fit together to make living organisms, contribute to development of lighter, higher-strength alloys for fuel-efficient transportation and advance the use of biomass for alternative fuels. Hard x-rays are also especially suited to the study of real materials, under realistic conditions and in real-time. The advances proposed in this area would help develop more efficient catalysts, enhance green manufacturing, point the way to artificial light-harvesting inspired by biology and help us develop more efficient lighting. The scope of the renewal of our $\sim \$ 1.5 \mathrm{~B}$ facility is estimated to be $\sim \$ 350 \mathrm{M}$ over five years. It is vital that the investment begin as soon as possible. The renewed APS would complement other national investments such as the National Synchrotron Light Source-II and would keep the U.S. internationally competitive. 


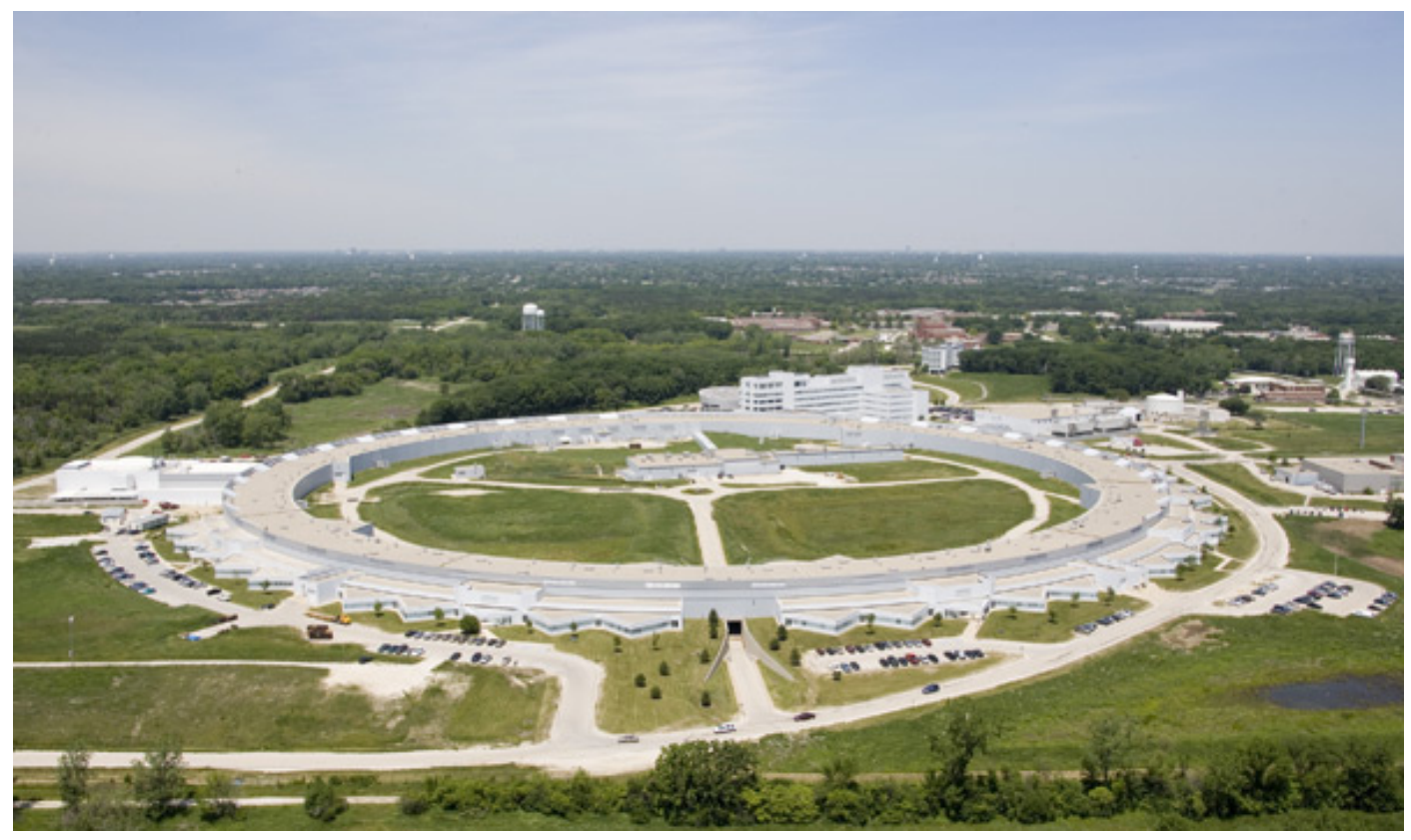

\section{Introduction}

Supported by the Department of Energy's Office of Science, Office of Basic Energy Sciences, the Advanced Photon Source (APS) serves the nation's largest scientific user community. Located in the Argonne National Laboratory near Chicago, each year the facility provides brilliant high-energy (or "hard") x-ray beams to 3500 users, who annually publish more than 1000 papers contributing to knowledge and innovation in energy, health, environment, physical and life sciences. At the core of the APS is a high-energy $7 \mathrm{GeV}$ electron accelerator which feeds a $1.1 \mathrm{~km}$ circumference storage ring whose undulators and bending magnets deliver x-rays to almost 60 independently operating beamlines. There are only two other high-energy $3^{\text {rd }}$-generation storage ring $\mathrm{x}$-ray sources operating around the world - the European Synchrotron Radiation Facility (ESRF) in Grenoble, France and the SPring- 8 facility in Harima, Japan. Both of these facilities are planning major upgrades. 
APS began operations in 1996. To address the future needs of users and provide the best hard x-ray capabilities to the United States, APS requires a major renewal that would bring it to the state-of-the-art within a decade. Innovations in many instruments and beam sources would generate orders of magnitude improvements in sensitivity and precision, deliver new capabilities that were not envisioned when the machine was built, and enable important experiments that cannot be accomplished today. The renewal plan was developed in an open process with our user community. The investments would take full advantage of our outstanding accelerator complex and skilled user base. Support for the APS renewal would complement other developments in the U.S. by offering the best source of hard x-rays.

\section{Scientific Vision for a Renewed APS}

We invited input from our existing and potential user community to identify the innovations that would have revolutionary impact and address important scientific questions unanswerable with the capabilities available at APS today. Among the spectacular impacts on science and engineering research that were presented, we identified two overarching themes that will guide our investments for the APS renewal: Mastering hierarchical structures through $x$-ray imaging; and Real materials in real conditions in real time. For each theme we have singled out some high-impact problems whose solution will be aided by the APS renewal.

\section{Mastering hierarchical structures through x-ray imaging}

Hierarchical structures are pervasive - from machines to organisms. Because of their penetrating power, hard x-rays uniquely offer the ability to examine non-destructively the interior of hierarchical systems and characterize structure, composition and dynamics on length scales from $\mathrm{nm}$ to $\mathrm{cm}$. New developments in optics, beam stability, detectors and software are enabling revolutions in rapid imaging with hard x-rays inside large objects down to the nm length scale. 
With new imaging tools we will be able to address one of the most important problems in biology -

\section{How do proteins fit together to make}

organisms? Every organism is the outward physical manifestation (phenotype) of internallycoded inheritable information (genotype).

An overarching challenge is to link genotype and phenotype, connecting the avalanche of data on genetics to fundamental questions about biological

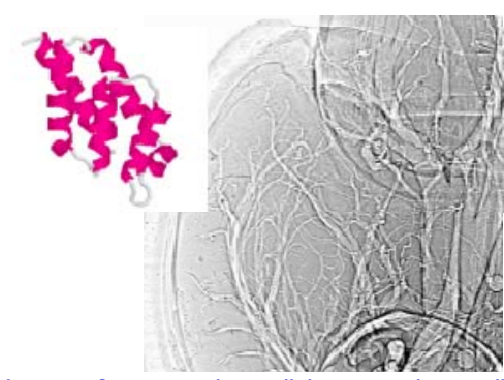

Images from proteins to living organisms will help connect the dots in understanding how genetics controls health and disease (Image at right courtesy W.K. Lee, ANL; (c) 2007

Socha et al; licensee BioMed Central Ltd.)

diversity, and to medical concerns such as why one individual but not another becomes ill in response to the same stress. Resolving these questions requires techniques that bridge the scale of molecular biology to that of entire organisms. APS is today the most productive source in the world for solving complex protein structures. Leveraging this capability at the molecular level with multiscale imaging on length scales from $\mathrm{nm}$ to $\mathrm{cm}$ will be transformative.

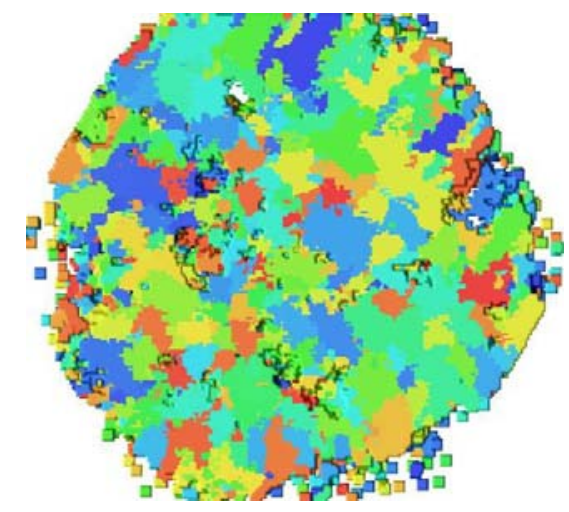

3-D distribution of grains in a $1 \mathrm{~mm}$ cube of Al (Image courtesy R. Suter et al., Carnegie Mellon University)
More than $8 \%$ of U.S. imported foreign oil could be saved if we could reduce the weight of trucks and cars by only $10 \%$, through the use of high-strength steels or $\mathrm{Al}$ alloys. Although the materials exist we cannot yet use them because we do not understand the "springback" in these complex materials associated with stamping of automobile body parts. Springback is just one example of an engineering problem that could be solved by better quantitative understanding and modeling of

deformation in polycrystalline materials enabled by advanced hard x-ray imaging developments at APS. The techniques can also be applied to innovative new nanocomposites that offer ultimate control of properties by imitating biological materials. 
Transport of environmental contaminants remains inadequately understood.

Advanced x-ray fluorescence imaging can address contamination problems ranging from safe storage of nuclear waste to cleaned-up manufacturing. Hard x-ray fluorescence is most appropriate to spatially resolve trace concentrations of contaminants, and promises to give important insight into the health and disease effects of metals in biology through sub-cellular imaging at the organelle level.

One of the most promising alternatives for petroleum-based fuel is ethanol obtained from biomass. Invaluable to understanding biomass conversion is imaging the molecular architecture of ligno-cellulose in plants and during processing into glucose, ethanol and other chemical products. More generally, complex tissue is a fruitful area of study for advanced x-ray imaging, where not only structure but mechanics can be revealed by imaging of stress distribution, addressing important medical problems such as prostheses. Other major x-ray imaging challenges include sequestration of carbon in rock, and fluid jets and sprays. The latter example, with application to improved engine efficiency, demands not only high spatial resolution, but also ultrafast imaging.

To address these and a myriad of other important questions will require the development of new dedicated high-performance imaging capabilities. Needs include one or more long beamlines to provide larger fields-of-view, higher spatial coherence to enhance phase contrast imaging of low atomic number materials, new x-ray optics for nanoscale focusing and faster detectors to take advantage of the high average brilliance of APS and allow fast time-dependent imaging. Better software for image analysis and real-time modeling is equally important. Better electron and photon beam stability and nanopositioning of samples will be enabling goals of the renewal project. Complementary scattering and spectroscopy techniques will be developed to bridge to the molecular scale. We also plan to develop a unique pulse-slicing source for hard x-rays that would be complementary to the new Linac Coherent Light Source (LCLS), offering tunable hard x-rays and time resolutions from 1 ps up to seconds or longer to use with imaging, diffraction and spectroscopy. These coupled developments will lead to orders of magnitude improvement in time resolution and sensitivity that will be needed to solve the scientific challenges. 


\section{Real materials in real conditions and real time}

Hard x-rays above $20 \mathrm{kV}$ are uniquely suited to penetrating complex environments and revealing atomic level structure. For example, APS researchers have studied combustion, materials under conditions of the earth's core, surfaces buried under liquids, operating fuel cells, and catalytic reactors. To enable the dreams of scientists and engineers and extend these experiments into new regimes, we must provide multiple techniques in one experiment to supplement the information from x-rays, and develop the ability to study in real-time and provide images. With optimized beamlines, including access to complementary measurements during in-situ experiments, improved detectors and optics, and enhanced data analysis capabilities, many important new experiments will become possible through the APS renewal. We also expect to attract a larger fraction of industrial users who are very interested in examining conditions used in manufacturing.

Developing catalysts with the specificity and activity of enzymes. Catalysts are key to the modern world, yet greatly improved catalysts are essential for development of sustainable energy. As an example, because we have been unable to develop catalysts with sufficiently high activity, fuel cells today contain very large loadings of precious metals. Yet we know that nature can produce catalysts (enzymes) that operate at low temperatures with very high activity and specificity, use readily

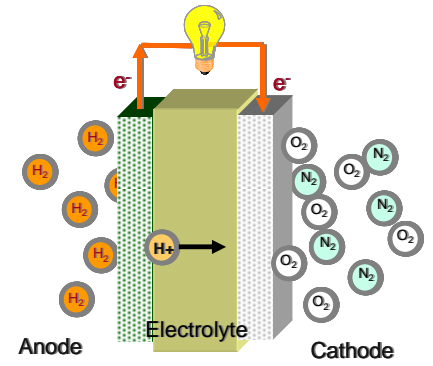
available metals, and are resistant to degradation even in "dirty" environments.

Further development of catalysts requires understanding and perfecting their structure and dynamics under operating conditions. Hard x-rays are uniquely able to penetrate high temperature, high pressure gas or liquid environments to reveal molecular structure and dynamics of heterogeneous catalysts. The added ability to image such structures and identify the active sites would be invaluable. High-speed acquisition of data is necessary to explore reaction dynamics. 


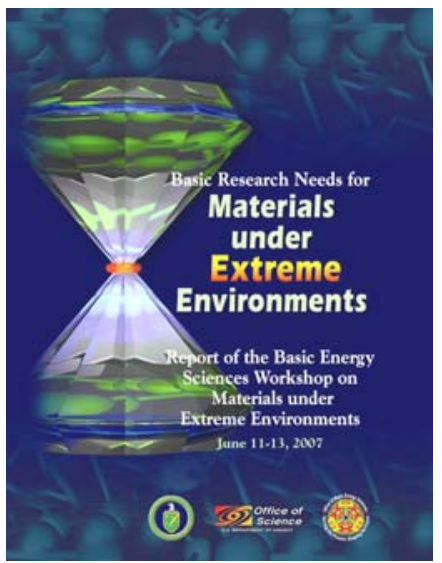

The cover of this BESAC report shows a diamond anvil cell. APS is a world-leader in high-pressure research.
The APS today is the most prolific source of high-impact papers in the area of high pressure science. These studies can be extended to more extreme conditions and shorter timescales. With new facilities for ultrafast compression and recording, we plan to enable new insights into dynamic shock compression physics. This would open up new regimes of extreme pressures and temperatures which cannot be sustained for long but also reveal energetic materials behavior important in weaponry.

About $20 \%$ of energy consumption in the U.S. goes to lighting, yet most lighting is very inefficient. Solid-state lighting represents a major improvement, and the development of high-quality cheap fabrication techniques will be favored by in-situ studies of materials growth.

Vast amounts of energy in sunlight are ripe for collecting if we can replicate nature's efficient mechanisms for photon-electron transfer. One key to artificial light-harvesting is understanding the complex chemical excited states involved in photosynthesis. Progress will be aided by the tunable high-average-brilliance $1 \mathrm{ps}$ source that would be developed at APS as a part of the renewal, accessing the large dynamic range of electron transfer after photoexcitation.

Nucleation is one of the most important phenomena controlling the structure, properties and failure mechanisms in materials, yet it is poorly understood. For example nucleation in liquids determines the structure and function of chemically synthesized precipitates, from film emulsion to food. A major reason for our lack of knowledge of nucleation is that it is often a rare event. With a combination of high-speed imaging detectors and realistic large samples, we believe that the nature of nucleation can be exposed by

“triggering" of detectors in analogy with methods developed by high-energy physicists. 
Similar approaches should shorten the cycle of development of new materials through efficient exploration of parameter space. Energy and other high-priority societal needs demand new materials with better functionality including thermoelectrics, solid-state battery electrolytes, superconductors, and magnets.

Common to the themes described in our scientific vision - hierarchical imaging and real materials - is extending into real time and going beyond structure to examine the dynamics of materials. APS is ideally suited for such studies over time scales from ps to hours, and is complementary to the ultrafast single pulse studies possible at the Free Electron Laser LCLS. Dynamical experiments will use diffraction, imaging and spectroscopy.

Our two overarching scientific themes do not encompass all the innovations that would be implemented in the APS renewal, but they are ubiquitous and the improvements they would spawn will pay off in other important areas of x-ray science at APS. For example, improved mechanical and beam stability will permit use of micron-sized crystals for protein structure determination, extending the method to a much larger number and wider range of proteins and assemblies than can currently be studied.

By developing capabilities with radically new scope addressing the two themes, together with complementary technique developments, we believe that the investment in APS renewal will be enormously rewarded by benefits to environmentally responsible energy production and use, making the Earth a healthier planet, a stronger and more sustainable economy, human health, and scientific knowledge. Highlights have been included in this whitepaper, but a much fuller account will be developed in a larger document, and further details can be seen at our website (http://www.aps.anl.gov/Renewal/). 


\section{National Context}

The table below lists the suite of major third-generation light sources in the United States, and two major light sources under construction. (The second-generation NSLS, which will be replaced by NSLS-II, is included for comparison.)

\begin{tabular}{|c|c|c|c|c|c|c|}
\hline Source Name & Location & Type & $\begin{array}{l}\text { 1st Year } \\
\text { Operation }\end{array}$ & $\begin{array}{l}\text { Characteristic } \\
\text { Energy }\end{array}$ & $\begin{array}{l}\text { Beam- } \\
\text { lines }\end{array}$ & $\begin{array}{l}\text { Users } \\
(2007)\end{array}$ \\
\hline Advanced Light Source & California & $\begin{array}{l}\text { Third-gen } \\
\text { storage ring }\end{array}$ & 1993 & $\begin{array}{l}3.2 \mathrm{keV} \\
\text { (12 keV } \\
\text { super-bend) }\end{array}$ & 43 & 1,784 \\
\hline Advanced Photon Source & Illinois & $\begin{array}{l}\text { Third-gen } \\
\text { storage ring }\end{array}$ & 1996 & $19.5 \mathrm{keV}$ & 60 & 3,420 \\
\hline $\begin{array}{l}\text { Linac Coherent } \\
\text { Light Source }\end{array}$ & California & $\begin{array}{l}\text { Free-electron } \\
\text { laser }\end{array}$ & 2009 & N/A & $\begin{array}{l}4 \\
\text { (instmnts) }\end{array}$ & N/A \\
\hline $\begin{array}{l}\text { National Synchrotron } \\
\text { Light Source }\end{array}$ & New York & $\begin{array}{l}\text { Second-gen } \\
\text { storage ring }\end{array}$ & 1982 & $7.1 \mathrm{keV}$ & 65 & 2,219 \\
\hline $\begin{array}{l}\text { National Synchrotron } \\
\text { Light Source II }\end{array}$ & New York & $\begin{array}{l}\text { Third-gen } \\
\text { storage ring }\end{array}$ & 2015 & $2.4 \mathrm{keV}$ & $\begin{array}{l}\sim 58 \\
\text { possible }\end{array}$ & N/A \\
\hline $\begin{array}{l}\text { Stanford Synchrotron } \\
\text { Radiation Laboratory }\end{array}$ & California & $\begin{array}{l}\text { From second } \\
\text { to third-gen } \\
\text { storage ring }\end{array}$ & $\begin{array}{l}1973 \\
\text { (upgraded } \\
\text { in 2004) }\end{array}$ & $7.5 \mathrm{keV}$ & 34 & 1,151 \\
\hline
\end{tabular}

Of these productive and complementary sources the APS is unique with its high characteristic x-ray energy, and very large user community. The APS will remain the only major hard x-ray source in the United States for a decade or more. Renewal of APS will strengthen this role by providing world-class hard x-ray capabilities in the U.S. for decades to come. APS would complement the new NSLS-II in New York, which will deliver brilliant beams at intermediate x-ray energies, and the LCLS in California, that will deliver exceptionally bright single pulses at intermediate energies. Hard x-rays $(>20$ $\mathrm{keV}$ ) are unique in penetrating complex environments, thick objects and offering very high Q-space resolution. The application of these characteristics to important scientific problems forms the basis of our renewal proposal. Complementary developments in soft $\mathrm{x}$ ray science will be facilitated at ALS, NSLS-II and possible future light sources. In 
addition to synchrotron sources there are other facilities in the U.S., such as the Spallation Neutron Source in Tennessee, that use other types of radiation and probe matter in complementary ways.

\section{International Context}

The table below lists the only high-energy third-generation synchrotron sources operating or under construction in the world. The newest source, PETRA-III, will have lower emittance than the other three sources and will provide strong competition, although it will have relatively few beamlines.

\begin{tabular}{|c|c|c|c|c|c|c|}
\hline Source Name & Location & Type & $\begin{array}{l}\text { 1st Year } \\
\text { Operation }\end{array}$ & $\begin{array}{l}\text { Characteristic } \\
\text { Energy }\end{array}$ & $\begin{array}{l}\text { Beam- } \\
\text { lines }\end{array}$ & $\begin{array}{l}\text { User } \\
\text { Visits(06) }\end{array}$ \\
\hline Advanced Photon Source & US & $\begin{array}{l}\text { Third-gen } \\
\text { storage ring }\end{array}$ & 1996 & $19.5 \mathrm{keV}$ & 60 & 10,800 \\
\hline ESRF & France & $\begin{array}{l}\text { Third-gen } \\
\text { storage ring }\end{array}$ & 1994 & $20.3 \mathrm{keV}$ & 49 & 6,090 \\
\hline $\begin{array}{l}\text { PETRA III } \\
\text { Light Source }\end{array}$ & Germany & $\begin{array}{l}\text { Third-gen } \\
\text { storage ring }\end{array}$ & 2009 & $20.8 \mathrm{keV}$ & $\begin{array}{l}\text { 14(up } \\
\text { to } 20 \text { ) }\end{array}$ & NA \\
\hline SPring-8 & Japan & $\begin{array}{l}\text { Third-gen } \\
\text { storage ring }\end{array}$ & 1997 & $28.9 \mathrm{keV}$ & 48 & $N / A$ \\
\hline
\end{tabular}

ESRF and SPring-8 are engaged in renewal and upgrade. At SPring- 8 an XFEL is under construction, that will provide a stand-alone new capability and allow injection of single bunches into the storage ring. SPring- 8 is also engaged in beamline renovation and building, and planning for a new storage ring lattice upgrade in the next few years. The $\mathrm{ESRF}$ is in the advanced stages of securing 170MEuros capital investment for major beamline renovations, conceptually similar to the approach we are proposing for the APS renewal. We have benefitted from close involvement with these facilities: for instance a recent "Three-Way Meeting" on the subject of upgrade and renewal between SPring-8, ESRF and APS management was held in the spring of 2008 at APS. Our renewal will help us define the state-of-the-art in the key areas we have identified. Especially in imaging we need to develop new capabilities to compete internationally. Without a major renewal we would slip behind in most areas. 


\section{Development Process for the Renewal Plan}

For the last five years APS has been planning with its users for new high-priority scientific capabilities. The table below shows those workshops that have been held in just the last two years.

\begin{tabular}{|c|c|}
\hline Title & Date \\
\hline APS Renewal Planning Workshop & Oct $20-21,2008$ \\
\hline Small Angle Scattering: Beyond $\mathrm{R}_{\mathrm{g}}$ & Jun 28-Jul 2, 2008 \\
\hline Understanding Condensed Matter Dynamics at the Microscopic Level & Jun 23-24, 2008 \\
\hline $\begin{array}{l}\text { Workshop to Introduce High-Resolution Inelastic X-Ray Scattering on } \\
\text { Earth Materials using Synchrotron Radiation }\end{array}$ & May 31-Jun 1, 2008 \\
\hline Short Pulse X-Rays at the APS & May 9,2008 \\
\hline APS Upgrade / ERL Optics Workshop & Apr 23, 2007 \\
\hline $\begin{array}{l}\text { New Applied Materials Research from Improved } \\
\text { High Energy X-Ray Sources }\end{array}$ & Jul 28, 2006 \\
\hline Detectors & Jul 21, 2006 \\
\hline Sub-meV Energy Resolution & Jul 20, 2006 \\
\hline Microscopy & Jul 17, 2006 \\
\hline Biology and Life Sciences & Jul 14, 2006 \\
\hline New Structural Science from Improved High Energy X-Ray Sources & Jul 13, 2006 \\
\hline Picosecond Science & Jun 29, 2006 \\
\hline Novel Science with Polarized X-Rays & Jun 29,2006 \\
\hline Interfacial and Surface Science & Jun 29, 2006 \\
\hline Coherence/lmaging & Jun 15\&Jul 11, 2006 \\
\hline Workshop on Intermediate Energy X-Ray & Jun 13, 2006 \\
\hline Science Opportunities using X-Rays and Split Gap High-Field Magnets & Jun $8-9,2006$ \\
\hline Ultrafast SAXS & Jun 6, 22, 2006 \\
\hline Fourth CW and High Average Power RF Workshop & May 1-4, 2006 \\
\hline
\end{tabular}

The DOE held a major peer review of APS in December of 2007 which strongly recommended development of a renewal plan. Building on previous strategic planning we 
solicited specific proposals associated with the renewal and began discussion of these at the May 2008 User Meeting, attended by over 600 users. Each beamline at the APS, whether operated by the facility, or independently by a Collaborative Access Team, was encouraged to submit a science-based proposal on the investments needed to achieve world leadership. Forty-two beamline proposals were received. These were developed in close association with the user beamline advisory committees. Seven proposals for brand new beamlines were also submitted from the community and have received initial review from the Scientific Advisory Committee. Several of these could be accommodated at the three undeveloped insertion device lines that remain at APS, whereas others could be incorporated in redeveloped sectors. All these proposals and more information can be found on our website (http://www.aps.anl.gov/Renewal). Through a Renewal Steering Committee comprising facility and user representatives ${ }^{1}$, we appointed 10 science teams to identify the science drivers for future users of APS, and a number of technique coordinators to look at the instrumentation and expertise that would be needed to satisfy the science challenges. We also benefited from the recent decadal study of Condensed Matter and Materials Physics by the National Research Council and the Grand Challenges report of the Basic Energy Sciences Advisory Committee, which identified key scientific problems and the vital role of current and future light sources. At the APS renewal planning workshop in October 2008, we brought together 200 key users and staff to present these scientific visions to members of the Scientific Advisory Committee of the APS (listed on the next page), which provided the recommendations summarized in this document. The recommendations allow us to select and develop the highest priority proposals to include in the renewal project.

As we proceed with renewal planning, we will be holding a major set of workshops at the 2009 APS Users Meeting next May, and will continue our preconceptual design planning. With DOE approval of Critical Decision 0, we would develop a Conceptual Design Report (CDR), holding workshops and a SAC based review process to prioritize and select the

\footnotetext{
${ }^{1}$ Denny Mills, Rod Gerig, George Srajer, John Maclean (APS), Denis Keane (APS PUC Chair), Paul Fuoss (APSUO Rep), Bob Fischetti (Life Sciences Council Chair), Dan Neumann (SAC Member)
} 
detailed projects that would comprise the renewal. We expect that we could be ready with a CDR by the end of 2009 .

\section{APS Scientific Advisory Committee}

\begin{tabular}{|c|c|}
\hline Name & Research Field \\
\hline $\begin{array}{l}\text { Prof. Jens Als-Nielsen } \\
\text { Neils Bohr Institut, Copenhagen }\end{array}$ & X-ray physics \\
\hline $\begin{array}{l}\text { Dr. Michelle V. Buchanan } \\
\text { Associate Laboratory Director, Oak Ridge National Laboratory }\end{array}$ & $\begin{array}{l}\text { Molecular analysis, } \\
\text { protein interactions }\end{array}$ \\
\hline $\begin{array}{l}\text { Dr. Howard Einspahr } \\
\text { Research fellow, Bristol-Myers-Squibb (retired) }\end{array}$ & $\begin{array}{l}\text { Protein crystallography, } \\
\text { drug design }\end{array}$ \\
\hline $\begin{array}{l}\text { Prof. Janos Kirz } \\
\text { Scientific Director, Advanced Light Source }\end{array}$ & $\mathrm{X}$-ray microscopy \\
\hline $\begin{array}{l}\text { Prof. Miles V. Klein } \\
\text { University of Illinois (retired) }\end{array}$ & $\begin{array}{l}\text { Experimental condensed- } \\
\text { matter physics }\end{array}$ \\
\hline $\begin{array}{l}\text { Dr. Dan Neumann } \\
\text { NIST Center for Neutron Research }\end{array}$ & $\begin{array}{l}\text { Structure and dynamics } \\
\text { in molecular materials }\end{array}$ \\
\hline $\begin{array}{l}\text { Prof. Piero A. Pianetta } \\
\text { Deputy Director, Stanford Synchrotron Research Laboratory }\end{array}$ & $\begin{array}{l}\text { X-ray microanalysis, } \\
\text { especially surfaces and } \\
\text { interfaces }\end{array}$ \\
\hline $\begin{array}{l}\text { Dr. William Stirling } \\
\quad \text { Director General, European Synchrotron Research Facility }\end{array}$ & Magnetic scattering \\
\hline $\begin{array}{l}\text { Dr. Soichi Wakatsuki } \\
\text { Director, Photon Factory, Japan }\end{array}$ & Protein crystallography \\
\hline $\begin{array}{l}\text { Dr. Glenn Waychunas } \\
\text { Molecular Geochemistry Leader, } \\
\text { Lawrence Berkeley National Laboratory }\end{array}$ & $\begin{array}{l}\text { Synchrotron radiation } \\
\text { applied to geochemistry } \\
\text { and environmental science }\end{array}$ \\
\hline $\begin{array}{l}\text { Prof. Donald J. Weidner } \\
\text { Department of Earth and Space Sciences, } \\
\text { SUNY Stony Brook }\end{array}$ & Geophysics \\
\hline $\begin{array}{l}\text { Dr. Wei Yang } \\
\text { Chief, Structural Biology and Cell Signaling Section, NIH }\end{array}$ & $\begin{array}{l}\text { Molecular biology and } \\
\text { protein crystallography }\end{array}$ \\
\hline $\begin{array}{l}\text { Prof. Larry Lurio (ex-officio) } \\
\text { Northern Illinois University } \\
\text { Chair, APS Users Organization }\end{array}$ & $\begin{array}{l}\text { Coherent } x \text {-ray scattering } \\
\text { and physics of soft } \\
\text { materials }\end{array}$ \\
\hline $\begin{array}{l}\text { Dr. Denis Keane (ex-officio) } \\
\text { Director, DND CAT } \\
\text { Chair, APS Partner User Council }\end{array}$ & $\begin{array}{l}\text { Surface } x \text {-ray scattering } \\
\text { and reflectivity }\end{array}$ \\
\hline
\end{tabular}


Renewal of the Advanced Photon Source

\section{Estimated Cost and Schedule}

From our preliminary planning we estimate that the project will cost between $\$ 300$ and $\$ 400 \mathrm{M}$ and take between 5 and 7 years to complete. There will be little major civil construction involved, although some extensions to beamlines that require small outbuildings and additional laboratory space are desired. We have simultaneously developed a plan to deal with infrastructure and obsolescence issues at APS, which are becoming severe. This plan would be accomplished in parallel with the renewal, using our routine capital and accelerator improvement funds.

\section{Beyond the Renewal - the Opportunity for a Major Machine Upgrade}

Once the renewal is complete, APS will be in an excellent state for the next decade. In order to provide the best possible source of hard x-rays within the U.S. for the longer term, we are simultaneously exploring options for major upgrades to the accelerator that would build on the APS renewal investment. For example, next generation sources would offer greater coherence and shorter pulses that would build directly on the themes that we have developed for the renewal. Options we have considered range from third-generation lattice improvements, to fourth-generation concepts such as the Energy-Recovery LINAC, and the X-Ray Free Electron Laser Oscillator. While the lattice upgrades could be accomplished without significant further R\&D, they offer less dramatic improvements. We anticipate being involved in R\&D on the fourth-generation options in the next few years, and working with the Department of Energy as they plan for next generation capabilities in the U.S. The Basic Energy Sciences Advisory Committee is currently carrying out a national study of the need for fourth-generation light sources to address grand scientific and technological challenges. Our goal is to continue to lead the development of hard x-ray science in the U.S. and position the community for whatever next-generation investments may be made for hard x-ray sources in the decades to come. 
Renewal of the Advanced Photon Source 
Renewal of the Advanced Photon Source

\section{Argonne}

Advanced Photon Source

Argonne National Laboratory

9700 S. Cass Ave.

Argonne, IL 60439 USA

www.anl.gov

www.aps.anl.gov

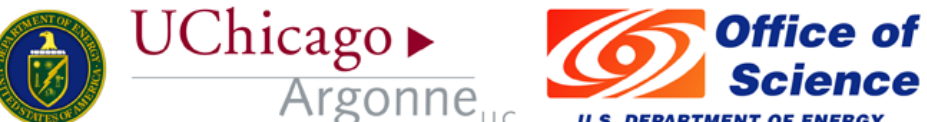

U.S. DEPARTMENT OF ENERGY 